\title{
Determinates of Women Micro-entrepreneurship Development: An Empirical Investigation in Rural Bangladesh
}

\author{
Lovely Parvin \\ College of Economics and Management, Northwest A\&F University \\ 3Taicheng Road, Yangling 712100, China \\ E-mail: 1rahman_bau@yahoo.com \\ M. Wakilur Rahman \\ College of Economics and Management, Northwest A\&F University \\ 3Taicheng Road, Yangling 712100, China \\ $\&$ \\ Faculty Member, Bangladesh Agricultural University \\ Mymensingh 2202, Bangladesh \\ E-mail: wakil_bau@yahoo.com \\ Jinrong Jia (Corresponding Author) \\ College of Economics and Management, Northwest A\&F University \\ 3Taicheng Road, Yangling 712100, China \\ Tel: 86-029-8708-1518Ｅ-mail: jinrong661@sina.com
}

Received: March 7, 2012

doi:10.5539/ijef.v4n5p254

\author{
Accepted: March 30, 2012 \\ Published: May 1, 2012 \\ URL: http://dx.doi.org/10.5539/ijef.v4n5p254
}

\begin{abstract}
The paper investigates the influencing factors of women micro-entrepreneurship development in rural Bangladesh. The analysis based on empirical investigation carried out in northern part of Bangladesh. Data were collected from 248 women micro-entrepreneurs and 132 non-entrepreneurs. Present study adopts three basic aspects such as personal attributes, family affairs and external environment to evaluate their contribution towards women entrepreneurship. Applying "probit" model, the study finds among various personal attributes, freedom of work and desire for higher social status significantly influenced to participate in micro-entrepreneurship. Family hardship also turns likely to be involved in micro-entrepreneurship. Among various external factors, access to credit, access to entrepreneurship training, membership with development organizations, access to information and favorable infrastructure depicts inspiring factors in participating micro-entrepreneurship. Study also indentifies several challenging factors toward smooth development of women micro-entrepreneurship. The paper provides suggestions for strengthening women entrepreneurship development process in rural Bangladesh.
\end{abstract}

Keywords: Women micro-entrepreneurship, Determinates, Development, Bangladesh

JEL Classification: M21 O31 and J 16

\section{Introduction}

Women "entrepreneurship development" is one of the crucial issues of contemporary development agenda in many developing countries. Entrepreneurship development and empowerment are complementary to each other. Women entrepreneur can be defined as a person who has alone or with one or more partners started or inherited a business eager to take financial, administrative, and social risks and responsibilities, and participating day-to-day management activities (UNDP, 2004). Women involvement in various entrepreneurial activities has empowered them in social, economic and cultural fields. The power of and access to taking decisions has increased for women within as well as outside the family (Nawaz, 2009). 
In Bangladesh, women constitutes about half of total population. The smooth development can not be attained bypassing women participation in the economic mainstreams. Realizing the importance, government of Bangladesh has distinctly provided some guidelines to strengthening women entrepreneurship development in the National Action Plan (NAP). It is noticeable that the Millennium Development Goal (MDG), the goal three (3) has proposed to promote gender equality and empower women in respect to education, employment and political empowerment. With the combined efforts of government and non-government organizations (NGOs), rural women's come forward to set up micro and small enterprises such as dairy raising, poultry rearing, petty business, handicrafts, daily hawker and so on. It is well recognized that women involvement in micro-enterprises depends on personal, socio-cultural and economic factors of a particular society. The gender discrimination that often prevails most of the societies have greater influence on women entrepreneurship development.

Concerning the matter a good number of studies have been carried out around the world focusing on micro enterprise development and women entrepreneurship. A study (as quoted in Das, 2000) of women entrepreneurs in the western world proposes three factors that influence entrepreneurship- antecedent influences (i.e., background factors such as family influences and genetic factors that affect motivation, skills and knowledge), the "incubator organization" (i.e., the nature of the organization where the entrepreneur was employed) and environmental factors (e.g., economic conditions, access to venture capital and support services, role models). These challenges are inherent in many countries some of them are more feasible in South and East Asian countries. Literature from Asian developing countries have attributed three aspects of women entrepreneurs such as "chance", "forced" and "created" (Raju, 2000; Seymour, 2001; Sharma and Dhameja, 2002; and Sinha, 2003). Chance entrepreneur means start a business without any clear goals or plans, forced entrepreneurs compelled by circumstances (e.g., death of a spouse, the family facing financial difficulties) and created entrepreneurs means "located, motivated, encouraged and developed" through entrepreneurship development programs. More importantly, Habibullah (1987) identifies training is an effective tool for entrepreneurship development in Bangladesh. Aktaruddin (1999) finds personal attributes are key factors for entrepreneurial success or failure, while Aktaruddin (2000) focuses on the socio-economic background of the entrepreneurs. Afrin et al (2008) finds that financial management skills and the group identity of the women borrowers have significant relationship with the development of rural women entrepreneurship in Bangladesh. On the other hand, Saleh (1995) study depicts, inadequate cash flows, marketing deficits and discriminating treatment from supportive service agencies create obstacles to women entrepreneurship development in Bangladesh.

Giving concentration on previous literatures, present paper aims to determine the influencing factors of women entrepreneurship development in rural Bangladesh. It is regarded that women entrepreneurship development has a close connection with entrepreneur personal attributes, family affairs and other external environment. Therefore, the study empirically investigates the catalyst of women micro-entrepreneurship development in the selected villages of Bangladesh. The article also identifies several hindering factors that create an obstacle at the beginning of women micro-entrepreneurship. The paper begins with providing some descriptive information then it determines the influencing factors of women entrepreneurship development applying econometric model and finally it identifies some challenging factors that hinder smooth development of women micro-entrepreneurship.

\section{Methods}

\subsection{Study Site Selection}

The foremost important part of socio-economic research is the selection of an appropriate study area and follows suitable sampling technique and data collection. The study area was selected in the northern part of Bangladesh, where agriculture is the dominating sector in the economy and women are involved in agricultural farming as well as non-farming activities. The study area comprises of twelve adjacent villages namely Chandipur, Jharuardanga, Kalkabari, Dangga, Bazarpara, Chitapara, Bara-horipur, Soto-horipur, Basirbania, Uttar-shalander, Dokhin-salander, and Dariapara of Bara-Chandipur union under Parbatipur Upazilla of Dinajpur district. The selected villages are nearby villages of the upazilla head-quarter and have a good history of micro-enterprises or non-farm activities.

\subsection{Sampling Techniques, Sample Size and Data Collection Procedure}

Both women micro-entrepreneurs and non-entrepreneurs were chosen as samples for this study. Complete survey technique was used for selecting women micro-entrepreneurs. Two hundred sixty women micro-entrepreneurs were found in the selected villages. Out of 260 micro-entrepreneurs, data were collected from 253. In fact, it was not possible to collect data from seven entrepreneurs because they were not available during data collection period. Among 253 samples five were found incomplete; hence 248 samples were used for analysis. On the other hand, a total 132 non-entrepreneur women were interviewed from the selected cluster villages. The primary data were collected through an interview schedule from micro-entrepreneurs and non-entrepreneurs. The field investigation 
was conducted in February and March, 2011. The secondary data were collected from Bangladesh Bureau of Statistics (BBS), Bangladesh Economic Review (BER), and Bangladesh Microfinance Statistics etc.

\subsection{Analytical Techniques}

Both descriptive and econometric analysis was comprehended to interpret the data. To find out the influencing factors toward women micro-entrepreneurship, the following probit regression function was fitted. Probit model helps to understand the impact of explanatory variables (personal attributes, family affairs and external environment) on the probability of participation in micro-entrepreneurship. The model was used by Panda (2009), Roodman and Morduch (2009), ADB (2007), Cheng and Ahmed (2010) and found suitable to explain the probability of participation as explanatory variables. Probit model can be written as follows:

$\mathrm{Yi}=\mathrm{f}\left(\mathrm{X}_{1}, \mathrm{X}_{2}, \mathrm{X}_{3}\right)+\mathrm{ei}$

$\mathrm{Y}=$ Type of women (if owner of micro-enterprise $=1$, otherwise $=0$ )

$\mathrm{X}_{1}=$ Personal attributes of women

$\mathrm{X}_{2}=$ Family situation

$\mathrm{X}_{3}=$ External/supportive environment

Insert Table 1 Here

\section{Results and Discussions}

\subsection{Profile of the Sample Respondent}

Basic information for women micro-entrepreneurs and non-entrepreneurs are shown in Table 2. It is depicted from Table 2 that the respondents were coming from young generation, the average age was roughly 34 years in both category (entrepreneur and non-entrepreneur). Similarly, average year of schooling was also found more or less similar for both categories. On the other hand, the family size for the non-entrepreneurs household was found little bit higher compared to entrepreneur households. The average family size had 3.58 and 3.80 for entrepreneurs and non-entrepreneurs household respectively.

Table 2 shows that women were involved in five categories of micro-enterprises such as dairy/livestock raising, poultry rearing, petty business, handicrafts and daily hawker. Among various micro-enterprises, livestock/dairy raising dominated in the selected villages consisting 35 per cent, afterwards poultry rearing (19\%), petty business $(18 \%)$, daily hawker $(17 \%)$ and handicrafts $(11 \%)$. It is evident from the empirical study that women were involved in micro-entrepreneurship at young stage of their life (Table 2). The average age of starting micro-entrepreneurship found roughly 27 years and the standard deviation value was 0.21 , justified that they were young entrepreneurs.

Insert Table 2 Here

\subsection{Determinates of Women Entrepreneurship}

The main objective of the study was to determine the influencing factors of women micro-entrepreneurship development in rural Bangladesh. Determinates of women entrepreneurship were measured based on three selected indicators such as personal attributes, family affairs and external environment. It was assumed that the mentioned three factors are main contributors toward involving micro-entrepreneurship. Among personal attributes- education, freedom of work, desire for higher income, desire for higher social status were assumed as influencing factors for participation in women micro-entrepreneurship. It was hyphothesied that higher level of education, freedom to work, desire for higher income and desire for higher social status may have induced rural women to take micro-entrepreneurship as means of self employment. Similarly, family size, family hardship, death of husband/earners and motivation of family/friends may have connection with taking micro-entrepreneurship. Meanwhile, the external factors such as access to credit, access to entrepreneurship training, government policy support, membership with entrepreneur organization, access to business information and favorable business infrastructure may also have leaded to involve in micro-entrepreneurship. With these assumptions present study adopted binary 'probit' model to determine the influencing factors for women micro-entrepreneurship development.

The log likelihood function and the proportions of samples correctly predicted for their likely status in terms of participation indicate a good fit of the equation (Table 3). It is apparent from the coefficient value of freedom of work and desire for higher social status that women got motivation to take micro-entrepreneurship (Table 3). Those family faced hardship were likely to be involved in micro-entrepreneurship. Among various external factors, access to credit, access to entrepreneurship training, membership with development organizations, access to information and favorable infrastructure encouraged in participating women in micro-entrepreneurship. However, formal education level, desire for profit, family size, death of husband/earners, motivation of family/friends and 
government policy supports were not found significant level of influence towards women entrepreneurship development although it was assumed to have somehow influence. The previous study conducted by Khan (2000) identifies following factors as influencing factors of rural entrepreneurship development in Bangladesh. These arefamilial business demonstrations, training for entrepreneurial skill development, technical knowledge, fortunate in getting good advisers, fortunate in obtaining sympathetic suppliers, abundant supply of local well wishers, blessed with all types of institutional facilities \& supports, availability of seed as well as working capital, favorable market contacts, Intimacy with some existing entrepreneurs. Almost similar findings of previous study obliviously demonstrated the significance of present empirical study outcomes on selecting determinates of women micro-entrepreneurship development.

Insert Table 3 Here

\subsection{Obstacles and Challenges of Women Entrepreneurship Development}

Following Table 4 shows the obstacles and challenges that women faced at starting their micro-enterprises. The standard question was asked "when you started your business, what were the main obstacles/challenges you faced?". Ten questions related to the obstacles and challenges were asked such as lack of self-confidence, lack of start up finance, lack of information, finding the right contacts for business venture, access to business support, management skills, entrepreneurial skills, combining family and enterprise works, gender discrimination and worried about societal acceptance. The collected responses are presented in the Table 4 including priority rank.

Among various obstacles lack of entrepreneurial skills were identified most challenging factors for starting micro-enterprises by the respondents (Table 4). The remaining challenges are presented based their ranks- lack of start up finance (rank- II), gender discrimination (rank-III) management skills (rank-IV), lack of information (rank-V), access to business support (rank-VI), lack of self-confidence (rank-VII) and finding the right contacts for your business venture (rank-VIII) while combining family \& enterprise works and worried about societal acceptance were jointly ranked IX. Similarly, Bhuiyan and Rubab (2007) empirical study in Bangladesh also identify following factors as challenging for women entrepreneurship development. The identified challenging factors were lack of awareness, excessive burden of work and responsibility, inadequate credit orientation, excessive tensions and managerial activities etc (Bhuiyan and Rubab, 2007). Therefore, it can be concluded that above mentioned factors are creating obstacles on smooth development of women entrepreneurship.

Insert Table 4 Here

\section{Conclusions}

Women entrepreneurship plays a vital role in economic development. Development of women entrepreneurship largely depends on internal as well as external factors such as personal attributes of the entrepreneurs, family affairs, government and other supportive organizational involvements. Main objective of the study was to determine the influencing factors of women micro-entrepreneurship development in rural Bangladesh. Applying binary Probit model, the study found among various personal attributes, freedom of work and desire for higher social status were significantly influenced women to participate in micro-entrepreneurship. Family hardship also turned likely to be involved in micro-entrepreneurship. Among various external factors, access to credit, access to skill training, membership with development organizations, access to information and favorable infrastructure were demonstrated as inspiring factors in participating micro-entrepreneurship. On the other hand, lack of entrepreneurial skills, lack of start up finance, gender discrimination, management skills, lack of information, access to business support, lack of self-confidence, finding the right contacts for business venture, combining family and enterprise works and worried about societal acceptance were identified as major challenges that women entrepreneurs faced at starting micro-entrepreneurship as means of self-employment.

Noticeably, Bangladesh government along with non-government organizations have taken several initiatives to encourage women getting involved in various micro, small and medium enterprises. However, considering greater importance of women entrepreneurship development towards balance socio-economic development there should have rights policy adjustment, their proper implementation and others necessary initiatives. These policy supports will not only contribute significantly to national economy but will economically and socio-culturally empower women. It will also create an opportunity for rural disadvantaged to maintain their livelihood through engaging in various micro-entrepreneurships. Therefore, government and development agency should come forward to facilitate women entrepreneurs' development.

\section{References}

ADB (2007). Managing for Development Results in the Asian development Bank: A Preliminary Assessment, Operations Evaluation Department, Asian Development Bank. 
Afrin, S., Nazrul, I., \& Shahid, U.A. (2008). A Multivariate Model of Micro Credit and Rural Women Entrepreneurship Development in Bangladesh. International Journal of Business and Management, 3, 169-185.

Aktaruddin, M. (1999). A Case Study of Some Successful and Unsuccessful Entrepreneurs in Bangladesh. Journal of Business Administration, 25, 89-126.

Aktaruddin, M. (2000). Socio-Economic Profile of Industrial Entrepreneurs: A Study on North Region of Bangladesh. A Journal of Banking and Finance, 25, 39-53.

Bhuiyan, M.B., \& Rubab, A. (2007). Women Empowerment through Entrepreneurship Development: Bangladesh Perspective. Daffodil International University Journal of Business and Economics, 2, 135-154.

Cheng, E., \& Abdullahi, D.A. (2009). The demand for credit, credit rationing and the role of microfinanceEvidence from poor rural counties of china, International Poverty Reduction Center in China (IPRCC) working paper series- 01, 2010. IPRCC, Beijing, China.

Das, D.J. (2000). Problems faced by women entrepreneurs, in K. Sasikumar (ed.), Women Entrepreneurship. New Delhi, Vikas Publishing House.

Habibullah, M. (1987). Entrepreneurship Training and Development, Chittagong: Chittagong University, Faculty of Commerce. Bureau of Business Research, 47-58.

Khan, A.R. (2000). Entrepreneurship Small Business and Lives of Successful Entrepreneurs. Dhaka, Bangladesh.

Nawaz, F. (2009). Critical Factors of Women entrepreneurship Development in Rural Bangladesh, Bangladesh Development Research Working Paper Series (BDRWPS) 5, Bangladesh Development Research Center (BDRC), 508 Fowler Street, Falls Church, VA 22046-2012, U.S.A. [Online] available: http://www.bangladeshstudies.org/files/WPS_no5.pdf (March 29, 2012).

Panda, K. D. (2009). Participation in the Group Based Microfinance and its Impact on Rural Households: A Quasi-experimental Evidence from an Indian State Global. Journal of Finance and Management, 1, 171-183.

Raju, G. (2000). Women entrepreneurship development through DWCRA, in K. Sasikumar (ed.), Women Entrepreneurship. New Delhi: Vikas Publishing House

Roodman, D., \& Jonathan M. (2009). The Impact of Microcredit on the Poor in Bangladesh: Revisiting the Evidence. Working Paper No. 174. Washington, D.C.: Center for Global Development.

Saleh, A. (1995). A Profile of the Women Entrepreneurship in Bangladesh. Journal of Business Studies, 16, 59-170.

Seymour, N. (2001). Women entrepreneurs in the developing world, CLCEE Digest No. 01-04, Kansas City, Center for Entrepreneurial Leadership, Clearinghouse on Entrepreneurship Education. [Online] available: http://www.celcee.edu/ (February 25, 2012).

Sharma, D. D., \& Dhameja, S. K. (2002). Women and Rural Entrepreneurship. Chandigarh: Abhishek Publications. Sinha, A. (2003). Experience of SMEs in South and South-East Asia, Washington, D.C. SEDF and World Bank. UNDP. (2004). Human Development Report 2004 (Oxford University Press). 
Table 1. Description of the variables

\begin{tabular}{|c|c|}
\hline Type of variable & Description of the variables \\
\hline Dependent Variables & Ownership of microenterprise, if yes $=1$, otherwise $=0$ \\
\hline \multicolumn{2}{|l|}{ Explanatory variables } \\
\hline \multicolumn{2}{|l|}{ Personal attributes $\left(\mathrm{X}_{1}\right)$} \\
\hline Education & Continues, year of schooling \\
\hline Freedom of work & Dummy, if yes $=1$, otherwise $=0$ \\
\hline Desire of higher income & Dummy, if yes $=1$, otherwise $=0$ \\
\hline Desire of higher social status & Dummy, if yes $=1$, otherwise $=0$ \\
\hline \multicolumn{2}{|l|}{ Family situation $\left(X_{2}\right)$} \\
\hline Family size & continues \\
\hline Family hardship & Dummy, if family having hardship $=1$, otherwise $=0$ \\
\hline Death of husband/wage earners & Dummy, if yes $=1$, otherwise $=0$ \\
\hline Motivation of family members/friends & Dummy, if yes $=1$, otherwise $=0$ \\
\hline \multicolumn{2}{|l|}{ Supportive environment $(X 3)$} \\
\hline Access to credit & Dummy, if yes $=1$, otherwise $=0$ \\
\hline Access to entrepreneurship training & Dummy, if yes $=1$, otherwise $=0$ \\
\hline Access to business information & Dummy, if yes $=1$, otherwise $=0$ \\
\hline Government policy supports & Dummy, if yes $=1$, otherwise $=0$ \\
\hline Membership with organizations & Dummy, if yes $=1$, otherwise $=0$ \\
\hline
\end{tabular}

Table 2. Descriptive statistics of the sample household

\begin{tabular}{|c|c|c|c|c|c|c|c|}
\hline \multirow[t]{2}{*}{ Particulars } & \multicolumn{6}{|c|}{$\begin{array}{c}\text { Type of micro-enterprise } \\
\text { Observations }=248\end{array}$} & \multirow{2}{*}{$\begin{array}{l}\text { Non-enterpri } \\
\quad \text { se } \\
\text { Observations } \\
=132\end{array}$} \\
\hline & $\begin{array}{l}\text { Dairy } \\
\text { raising }\end{array}$ & $\begin{array}{l}\text { Poultry } \\
\text { rearing }\end{array}$ & $\begin{array}{l}\text { Petty } \\
\text { business }\end{array}$ & handicrafts & Daily Hawker & Total & \\
\hline Respondent age & $\begin{array}{l}34.51 \\
(6.58) \\
\end{array}$ & $\begin{array}{r}34.00 \\
(6.22) \\
\end{array}$ & $\begin{array}{l}32.44 \\
(7.28) \\
\end{array}$ & $\begin{array}{l}30.96 \\
(8.68) \\
\end{array}$ & $32.04(6.24)$ & $\begin{array}{l}33.24 \\
(6.91) \\
\end{array}$ & $\begin{array}{r}33.97 \\
(6.53) \\
\end{array}$ \\
\hline Respondent Education & $\begin{array}{l}6.76 \\
(2.84)\end{array}$ & $6.62(2.44)$ & $\begin{array}{l}6.53 \\
(2.38)\end{array}$ & $5.29(1.53)$ & $6.22(2.06)$ & $\begin{array}{l}6.44 \\
(2.46)\end{array}$ & $\begin{array}{l}6.67 \\
(2.42)\end{array}$ \\
\hline Family size & $\begin{array}{c}3.53 \\
(1.08)\end{array}$ & $3.68(0.80)$ & $\begin{array}{c}3.53 \\
(1.09)\end{array}$ & $3.59(1.21)$ & $3.61(0.99)$ & $\begin{array}{l}3.58 \\
(1.03)\end{array}$ & $\begin{array}{l}3.80 \\
(0.90)\end{array}$ \\
\hline Enterprise (no.) & 87 & 48 & 45 & 27 & 41 & 248 & \\
\hline Enterprise (\%) & 35.08 & 19.35 & 18.15 & 10.89 & 16.53 & 100 & \\
\hline Enterprise starting age & $\begin{array}{l}28.91 \\
(5.90)\end{array}$ & $\begin{array}{r}28.97 \\
(5.60)\end{array}$ & $\begin{array}{l}25.91 \\
(6.59)\end{array}$ & $\begin{array}{l}23.70 \\
(7.47)\end{array}$ & $24.93(5.84)$ & $\begin{array}{l}27.15 \\
(0.21)\end{array}$ & \\
\hline
\end{tabular}

Parenthesis indicates the standard deviation 
Table 3. Determinants of women micro entrepreneurship development

\begin{tabular}{|c|c|c|c|c|}
\hline Variable & Coefficient & Std. Error & z-Statistic & Probability \\
\hline Entrepreneur education & $(0.028)$ & 0.027 & $(1.035)$ & 0.300 \\
\hline Freedom of work & 0.151 & 0.294 & 0.512 & 0.608 \\
\hline Desire for profit & 0.656 & 0.499 & 1.314 & 0.188 \\
\hline Desire for higher social status & 0.081 & 0.189 & 0.432 & 0.665 \\
\hline Family size & $(0.083)$ & 0.072 & $(1.152)$ & 0.249 \\
\hline Family hardship & 0.159 & 0.263 & 0.603 & 0.546 \\
\hline Death of Husband/family member & $(0.225)$ & 0.146 & $(1.535)$ & 0.124 \\
\hline Motivation by family members/friends & 0.199 & 0.159 & 1.248 & 0.211 \\
\hline Access to credit & 0.054 & 0.145 & 0.375 & 0.707 \\
\hline Access to skill training & 0.048 & 0.142 & 0.338 & 0.735 \\
\hline Government support & $(0.259)$ & 0.140 & $(1.847)$ & 0.064 \\
\hline Membership with entrepreneur organization & 0.073 & 0.165 & 0.441 & 0.658 \\
\hline Access to business information & 0.089 & 0.139 & 0.644 & 0.519 \\
\hline Business infrastructure & 0.081 & 0.139 & 0.580 & 0.561 \\
\hline Mean dependent var. & 0.652 & \multicolumn{2}{|l|}{ S.D. dependent var. } & 0.476 \\
\hline S.E. of regression & 0.479 & \multicolumn{2}{|l|}{ Akaike info criterion } & 1.344 \\
\hline Sum squared & 83.917 & \multicolumn{2}{|l|}{ Schwarz criterion } & 1.499 \\
\hline Log likelihood & $(240.41)$ & \multicolumn{2}{|l|}{ Hannan-Quinn criter. } & 1.406 \\
\hline Avg. log likelihood & $(0.632)$ & & & \\
\hline \multicolumn{5}{|c|}{ Dependent Variable: Women Micro entrepreneurship } \\
\hline \multicolumn{5}{|c|}{ Method: ML - Binary Probit (Quadratic hill climbing) } \\
\hline \multicolumn{5}{|c|}{ Included observations: 380} \\
\hline Observations with Dep. $=0$ & 132 & & & \\
\hline Observations with Dep. $=1$ & 248 & & & \\
\hline
\end{tabular}

Parenthesis indicates the negative value

Table 4. Problems and challenges of women entrepreneurship development

\begin{tabular}{|l|c|c|}
\hline Problems and Challenges & Mean value & Rank \\
\hline Lack of self-confidence & 0.69 & VII \\
\hline Lack of start up finance & 0.75 & II \\
\hline Lack of information & 0.72 & V \\
\hline Finding the right contacts for your business venture & 0.68 & VIII \\
\hline Access to business support & 0.71 & VI \\
\hline Management skills & 0.73 & IV \\
\hline Entrepreneurial skills & 0.76 & I \\
\hline Combining family and enterprise works & 0.65 & IX \\
\hline Gender discrimination & 0.74 & III \\
\hline Worried about societal acceptance & 0.65 & IX \\
\hline
\end{tabular}

